\title{
Learning 2.0 in Knowledge Economy: A Case Study of a Pilot Project in Zambia
}

\author{
Juseuk Kim \\ Assistant Professor \\ Joongbu University
}

Korea

Received: April 23, 2017

Accepted: July 20, 2017

Published: May 20, 2017

doi:10.5296/ijrd.v4i2.11110

URL: http://dx.doi.org/10.5296/ijrd.v4i2.11110

\begin{abstract}
This paper explores how Learning 2.0 in a knowledge economy can promote African higher education. It uses a case study of the pilot project in Zambia. The paper begins by showing that Learning 2.0 used in a knowledge economy is changing the nature of learning and providing new possibilities for learning. As higher education is a key factor for national development in knowledge economy, this is important for Africa. But Africa has few resources to expand quality tertiary education. An innovative project in Zambia uses Learning 2.0 to overcome some of these challenges and deliver quality higher education. The article shows how the project works and discusses some of the remaining challenges. In conclusion, the concept of the project presents that elements of the learning 2.0 in the knowledge economy can help to spread the higher education in developing countries.
\end{abstract}

Keywords: Knowledge-Based Economy, Learning 2.0, Higher Education, Global Knowledge Alliance, Learning Management System

\section{Introduction}

Learning 2.0 is changing the nature of learning and showing new possibilities for learning by providing a new educational experience for learners. And higher education is becoming a key factor for national development in the knowledge economy. However, countries in Africa constitute a very low proportion of the tertiary educated population in comparison with other parts of the world. In order to overcome this situation in Africa, this paper proposes that Learning 2.0 promotes the expansion of the existing higher education system using technology development and a learner centered LMS (Learning Management System) environment. Based on a case study of the GKI (Global Knowledge Institute) pilot project in Zambia, this paper examines how Learning 2.0 in the knowledge economy can promote 
higher education in Africa. Therefore, this paper will examine literature that looks at the necessity of higher education in Africa (knowledge economy, African higher education, Learning 2.0), and will examine how Learning 2.0 can positively influence higher education in Africa. I then examine key concepts (features) of Learning 2.0. Finally, I turn to an analysis of the pilot project case study. This project shows how these concepts can be put into practice.

\section{Review of Literature}

\subsection{Higher Education in a Knowledge Economy}

During the second half of the 20th century, the development of information and communication technology has brought a wave of change in the history of mankind. This phenomenon was referred as the 'Third Wave' by Alvin Toffler (1996). The 'Third Wave' reflects the transformation of human development from a nomadic society to an agrarian society, into an industrial society, and finally into a post-industrial economy.

Thurow \& Cunningham (1999) suggested that the 21st century is the era of the knowledge revolution, and that knowledge is the source of all individuals, companies, and countries to create wealth.

Table 1. Economic paradigm of the knowledge-based economy

\begin{tabular}{|c|c|c|c|}
\hline & $\begin{array}{l}\text { 17th beginning of } \\
\text { the 19th century } \\
\text { (Feudal era) }\end{array}$ & $\begin{array}{l}19 \text { to the second } \\
\text { half of the 20th } \\
\text { century (industrial } \\
\text { capitalism era) }\end{array}$ & $\begin{array}{l}\text { Since the second } \\
\text { half of the 20th } \\
\text { century } \\
\text { (Knowledge-based } \\
\text { economy era.) }\end{array}$ \\
\hline $\begin{array}{l}\text { A source of } \\
\text { competitive } \\
\text { advantage }\end{array}$ & Material resources & Industrial capital & $\begin{array}{l}\text { Knowledge (human } \\
\text { capital) }\end{array}$ \\
\hline $\begin{array}{l}\text { Main competition } \\
\text { content }\end{array}$ & Cost-competitive & Quality competition & Competition time \\
\hline $\begin{array}{l}\text { Key } \\
\text { technology-based }\end{array}$ & $\begin{array}{l}\text { Agricultural } \\
\text { Technology }\end{array}$ & $\begin{array}{l}\text { Industrial Science } \\
\text { and Technology }\end{array}$ & $\begin{array}{l}\text { Information and } \\
\text { Communication } \\
\text { Technology }\end{array}$ \\
\hline $\begin{array}{l}\text { The primary source } \\
\text { of wealth, and the } \\
\text { main industry }\end{array}$ & $\begin{array}{l}\text { Land-based } \\
\text { economy. } \\
\text { Agricultural } \\
\text { fishery products }\end{array}$ & $\begin{array}{l}\text { Machinery, } \\
\text { finance-based } \\
\text { economy. } \\
\text { Manufacturing }\end{array}$ & $\begin{array}{l}\text { Knowledge-based } \\
\text { economy. } \\
\text { Finance, hospitality }\end{array}$ \\
\hline $\begin{array}{l}\text { Amount and speed } \\
\text { of Knowledge } \\
\text { changes }\end{array}$ & $\begin{array}{l}\text { Small amount } \\
\text { Very Slow }\end{array}$ & $\begin{array}{l}\text { Mass } \\
\text { Long-term (one year } \\
\text { or more) }\end{array}$ & $\begin{array}{l}\text { Amplifier } \\
\text { Occasional } \\
\text { short-term (change) }\end{array}$ \\
\hline Growth principles & Limit growth & $\begin{array}{l}\text { Restrictive limit } \\
\text { growth }\end{array}$ & Sustainable growth \\
\hline
\end{tabular}




\begin{tabular}{|c|c|c|c|}
\hline $\begin{array}{l}\text { Economic activity } \\
\text { space }\end{array}$ & Local economy & national economy & $\begin{array}{l}\text { Global economy and } \\
\text { the expansion of the } \\
\text { virtual space }\end{array}$ \\
\hline $\begin{array}{l}\text { Economic } \\
\text { Operating } \\
\text { (mainstem } \\
\text { activities) }\end{array}$ & $\begin{array}{l}\text { The feudal system } \\
\text { and the state-led } \\
\text { (Bureaucratic) }\end{array}$ & $\begin{array}{l}\text { National and } \\
\text { enterprise-centric } \\
\text { Antagonistic } \\
\text { economic relations } \\
\text { (Technician) }\end{array}$ & $\begin{array}{l}\text { Enterprise-led } \\
\text { Cooperative } \\
\text { economic relations } \\
\text { (Knowledge of the } \\
\text { government, } \\
\text { intellectuals, } \\
\text { knowledge } \\
\text { company) }\end{array}$ \\
\hline $\begin{array}{l}\text { Core functions of } \\
\text { the government }\end{array}$ & $\begin{array}{l}\text { Production and } \\
\text { distribution of goods }\end{array}$ & $\begin{array}{l}\text { Regulation } \\
\text { intervention }\end{array}$ & $\begin{array}{l}\text { Support and } \\
\text { knowledge } \\
\text { cultivating }\end{array}$ \\
\hline
\end{tabular}

Source: Park (2002), p. 132.

Table 1 shows the characteristics of the knowledge-based economy compared with previous economic eras. This table show each economic element is approached differently within economic eras. Specially, it shows that the primary source of wealth and industry has changed and that knowledge has become the main resource in the second half of the 20th century

In the knowledge-based economy, knowledge is the most meaningful resource, rather than the level of the traditional factors of production such as labor, land, capital (Drucker, 1993). Additionally, Peter Drucker used the term 'knowledge economy' in 1966 in the book The Effective Executive. Following his book, he separated knowledge workers and manual workers. He went on to describe manual workers as people who produce goods or services using their hands. On the other hand, knowledge workers produce ideas, knowledge, and information using their head (knowledge).

In other words, the knowledge-based economy means changing the main factors of production from labor, land and capital of the industrial economy to knowledge and information. This knowledge will be shared among members in conjunction with the organization's history and experience, and other resources will ultimately be replaced by knowledge (Toffler, 1990).

Additionally, New Growth Theory offers an explanation of the movement from a resource-based economy to a knowledge-based economy. The most important feature of New Growth Theory, which is based on the knowledge economy, is that knowledge leads to growth. Because we can reuse and share knowledge and ideas constantly, knowledge can be used without restriction. Following New Growth Theory, the development of technology and knowledge finding is the most effective factors for the development of the country (Romer, 1998).

These characteristics are based on the knowledge economy. And the production, distribution 
and use of knowledge are directly linked to the knowledge economy. In addition, the knowledge economy can be defined as a visible trend of increasing investment in high-tech industries, high-skilled labor, and productivity gains associated with it. Therefore, higher education is an important input factor as knowledge is the most important economic resource in the knowledge economy. In the knowledge economy, the higher education system plays an essential role (Birdsall, 1996). Therefore, manpower within higher education is a very important issue in this knowledge-based economy. Higher education has been recognized as a key driver for socio-economic development and human resource development.

Investment in education is closely related to quantitative and qualitative growth of national well-being. Many studies demonstrated that investment in education contributes to the growth of the economy (Lian \& Oneal, 1997; Barro, 2002; Psacharopoulos, 1984; Harbison \& Myers, 1964; Schultz, 1963; Denison, 1962). In addition, investing in education, as well as quantitative indicators such as economic growth, have a positive effect on the development of qualitative indicators that determine the social, health, life, citizenship, crime, poverty, and national competitiveness in the non-monetary area (Dee, 2004; Kenkel, 1991; Strauss, Gertle, \& Rahman, 1993; Lochner \& Moretti, 2003).

\subsection{Higher Education in Africa}

African countries need higher education for the sustainable development of the knowledge economy. International organizations such as UNESCO, the World Bank, the European Union and the African Union expect that it would be difficult for the sustainable development of developing countries without higher education systems (World Bank, 2009). Nevertheless, the higher education enrollment rate is increasing, but still very low. Most African countries have a poor level of quality in higher education services due to a lack of resources and support for higher education (Pillay, 2008).

A significant portion of students attend publicly funded institutions in developing countries, but funding is insufficient. Specially, the higher education system is being less focused than other educational areas (Birdsall, 1996). Ilon \& Altmann (2012) proposed two problems for Africa higher education. First, there is no linking of higher education to local problems. Second, even though there is some funding for primary and secondary education, higher education is poorly supported. In 1995, public support for higher education in sub-Saharan Africa, East Asia and the Pacific, and South Asia was only 2\% to 3\% of GDP (Bloom \& Rosovsky, 2006).Specially, the government has difficulty in supplying the primary, secondary, and higher education systems due to the environmental change and political and historical conflicts in Africa (Leary \& Berge, 2007).

Additionally, numerous studies suggest a close correlation between higher education and economic development (Shaw, \& Allison, 1999; Lin, 2004; De Meulemeester, \& Rochat, 1995). And Bloom, Canning, \&Chan's (2006) study pointed out that the investment in education for developing countries has mainly focused on primary and secondary education. They emphasized the importance of higher education for poverty reduction and economic development in developing countries. 


\section{Macrothink}

However, although African countries need more higher education population, there is lack of higher education in Africa countries. There exists a significant disproportion of the higher education enrollment between industrial countries and developing countries as shown in Figure 1.

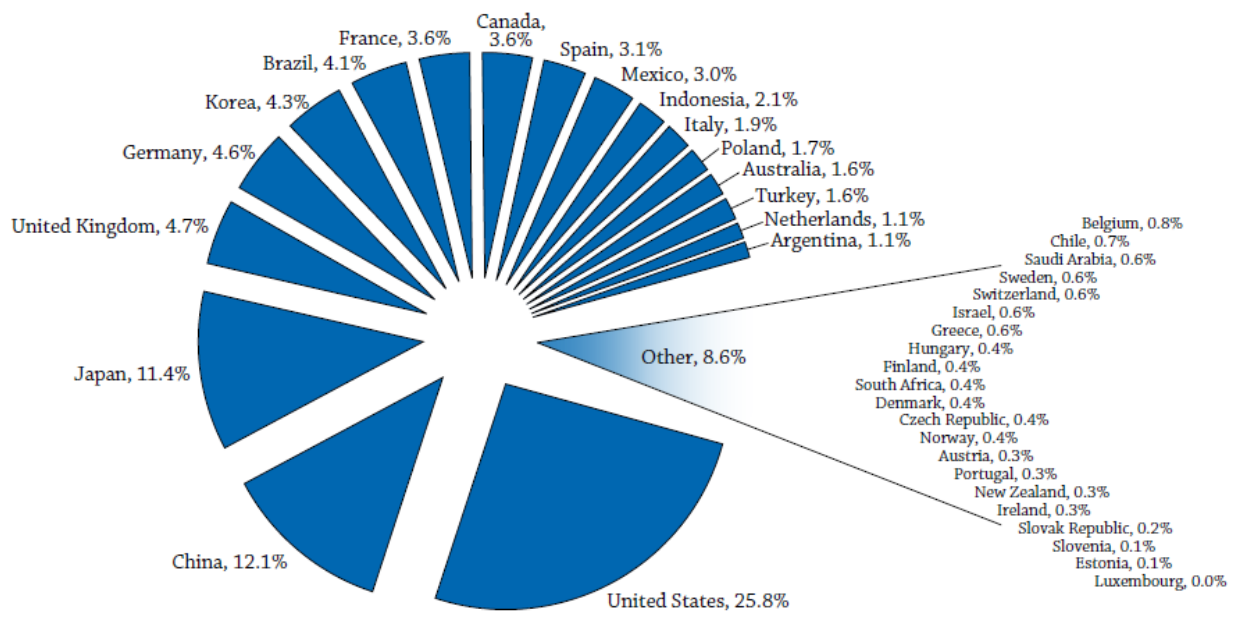

Note: Argentina refers to year 2003, China refers to year 2000, Saudi Arabia refers to year 2004, Indonesia and South Africa refer to 2007.

Figure 1. Countries' share in the total 25-64 year-old population with tertiary education percentage (2009)

Source: OECD (2011), Education at a Glance 2011.

African countries' share in the total 25-64 year-old population with tertiary education percentage is only $0.4 \%$ in the world. With the exception of South Africa, African countries did not represent even $0.1 \%$ of tertiary educated populations of the world.

Knowledge and creativity is important for information-based economy. Therefore, number of top ranked universities is more important than the number of universities in the country. But, on the basis of top 400 THE(Times Higher Education) World University Ranking in 2012-13, Africa countries have no universities in the top 400 universities list exempting South Africa's four universities .

\subsection{Learning 2.0 as a New Learning Theory for the Higher Education}

Development of technology enabled the emergence of Web 2.0. Web 2.0 changed the internet environment from passive production to active participation, and contributed to the spread of e-learning 2.0. Learning 1.0 was the teacher-centered learning method from the past, whereas Learning 2.0 is a learner-centered learning method emphasizing interactions of teaching and learning (Jokisalo \& Riu, 2009). Table 2 shows this contrast.

Table 2. (e-)Learning 1.0 to (e-)Learning 2.0 


\section{MInstitute ${ }^{\text {Mink }}$}

\begin{tabular}{|l|l|}
\hline (e-)Learning 1.0 & (e-)Learning 2.0 \\
\hline Learning Platform \& Learning Management Systems (LMS) & Personal Learning Environments (PLEs) \\
\hline Acquisition processes & Participation processes \\
\hline Multimedia (interactivity) & Social networks / Communities of Practice (CoP) \\
\hline Externally provided content & User-created content \\
\hline Curricula & Learning diaries/e-portfolios \\
\hline Course structure & Communication \\
\hline Tutor availability & Learner and peer interaction \\
\hline Quality assessed through experts & Quality assessed through learners and peers \\
\hline
\end{tabular}

Source: Ehlers et al. (2008).(e-)Learning 1.0 to (e-)Learning 2.0.

Learning 2.0 is providing a new educational experience for learners (Conole, 2012). In the learning 2.0 environment, personal learning environment (PLE) becomes an important tool for learning. At the same time the Learning Management System (LMS) is expanded. Free and Open Source Software (FLOSS) and Open Education Resources (OER) are critical components (Creţu, 2013).

Specially, social learning networks are being activated. Learning 2.0 is changing the awareness and the way of learning. Web 2.0 allows building a database of learning materials in cooperation with students (Hwang, Chen, Chu \& Cheng, 2012).

Additionally, Learning 2.0 can promote the expansion of the existing higher education system using many tools that are simple, often inexpensive and easy to deploy. First, technology development supports the distribution of higher education in the Learning 2.0 era. Researches on the higher education using digital devices are showing a snapshot of the current higher education and the current situation of e-learning for higher education(Morris, Ramsay \& Chauhan, 2012; Peña, 2010). The learning environment using smart phones and tablets has played a pioneering role for the Ubiquitous Personal Learning Environment (UPLE) (Taraghi, 2012). Using a mobile system, various attempts have been made that can provide the learning content to students (Hwang, Chen, Chu \& Cheng, 2012). M-learning is not expensive and is not technically complex. Therefore, using wireless networks, an extension of the existing higher education system can be facilitated (Creţu, 2013). M-learning can be a pioneering role for the configuration of UPLE in the Learning 2.0 era.

Secondly, educational systems which integrate Learning 2.0 create a learner-centered LMS environment. In the existing system of higher education, LMS has mainly focused on the educator-centered education, efficiency, and course management. However, in the era of Learning 2.0, the Social Learning Management System (SLMS) and Personal Learning Environment (PLE) is becoming more and more important. And the use of Open Educational Resources (OER) presents a new model for learning in higher education. These innovations are also presenting open and collaborative educational practices (Creţu, 2013). Learning 2.0 and Social Learning make it easier to construct a Personal Learning Environment (PLE) (Targhi, Ebner, \& Kroell, 2012).

Thus we can summarize the Key concept of e-learning 2.0 as follow: Free and Open Source 


\section{Macrothink}

Software (FLOSS); Open Education Resources (OER); Personal Learning Environment (PLE); Social Learning Management System (SLMS); Extended Learning Management System (ELMS); Open, collaborative Educational Practices (OEP).

\section{Project Result}

\subsection{The Global Knowledge Alliance}

These Learning 2.0 elements can be found in the pilot project. The pilot project was financially supported by the Korea National Research Foundation (KNRF) and implemented by a research team at Seoul National University (SNU) from October 1, 2011 to September 30th, 2012, and from October 1, 2013 to September 30th, 2015. And the project was first initiative supported by The Global Knowledge Alliance (GKA). GKA was designed to: make higher education more relevant to poor countries; make higher education more affordable for poor countries; provide a more sustainable alternative or other private higher education systems; link higher education to community and local development.

The most important concept of the project is the Knowledge Resource Value Chain. Knowledge of the local villages had generally been given little value in the global world. The relationship between global knowledge and local knowledge was a top-down relationship rather than mutually-beneficial relationship. The world, however, is growing more closely linked due to the transportation, communication, trade and technology linkages. Local problems related with health, environmental, political, social, and economic issues can create other problems in the global community, or show the same problem in other regions. In order to solve this problem, each region and the global community have to pay the costs.

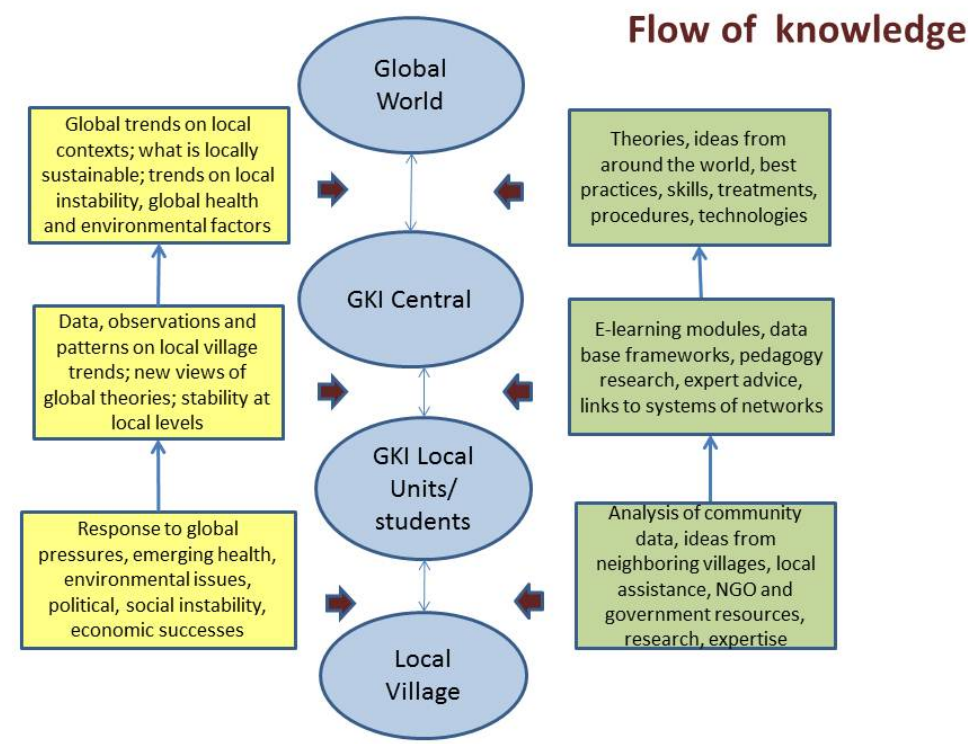

Figure 3. Flow of Knowledge

Source: GKA (2013) Global Knowledge Alliance. 


\section{Macrothink}

Figure 3 shows that knowledge flows two-ways. The flow of knowledge connects global world knowledge with local village knowledge. The various events or circumstances in the local village are collected and analyzed by the students' local units as a first step in the flow of knowledge. In this figure, one of most important things is that the data is highly connected and based with each local community. Additionally, this database can be distinctive with the data of international organizations as it mainly focuses on local communities rather than at country level data. In this way, global experts gain practical and theoretical insights about regional trends. But, equally important, local students and researchers participate in the process of solving local problems with the local context and adopt global knowledge to local conditions. The data can also be applied to local communities to help them build local solutions. The two-way flow of knowledge network adds value to all participants by recognizing that local and global knowledge can be combined to have value and knowledge creation has value as well as knowledge banking.

Eventually the knowledge produced through the interaction of global knowledge and local knowledge has real value. And the value of knowledge can be exchanged in its purest form rather than the one-sided flow of value. Finally, this knowledge exchange is helpful in reducing the cost of a local higher education as seen in Figure 4.

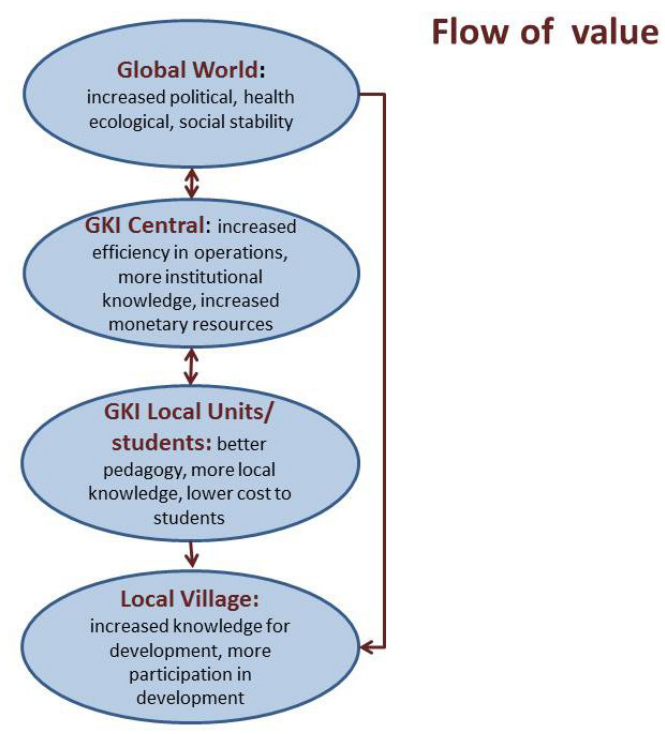

Figure 4. Flow of Value

Source: GKA (2013) Global Knowledge Alliance.

Additionally, Figure-1 shows that each unit in the flow of value system has a different role. Each unit will produces something of value, and this value formation is organically connected with each other. The flow of this value formation is not a one-way flow but a two-way flow which makes it possible to create value with each other. Eventually, this interactive flow of value contributes to the sustainable development of local communities. This value creation 


\section{Macrothink}

International Journal of Regional Development

ISSN 2373-9851

2017, Vol. 4, No. 2

brings benefits that do not have to be converted to monetary form - thus reducing the monetary burden of learning and the institutional cost. Each unit can be examined through this lens.

\section{i. Local}

The knowledge flow concept can help communities to build their ability to work with larger networks of resources, people and organizations. And local and global organizations can share opportunities to build new ideas in a networked, collaborative environment.

First of all, local communities can benefit from increased learning potential, local and global networks as partners, and planning, negotiation and networking skills. Additionally, local communities would contribute to indigenous knowledge and mechanisms, local resources and people, and a willingness and commitment for their sustainable development. Local communities would create value within the local-global network by supplying enhanced expertise from indigenous perspectives in development, creating a hospitable environment for students and research experts, managing resources indigenously, and implementing community projects for sustainable development.

\section{ii. Student learning}

Local students can benefit from a higher quality education, better career prospects, skills in using technology to build new knowledge, and exposure to global networks. They can also learn how to connect with the rest of the world using 21 st century digital technology, and how to apply global skills in local communities. Additionally, students would contribute to academic knowledge in various fields of studies, and also with work and industrial experiences in various sectors.

Therefore, students can offer contribute value in terms of global networking. They can develop the relationship amongst institutions, communities and organizations. They can also develop documents and learning processes in and with communities. Finally, they can implement project designs with community members for local community progress.

\section{iii. Global revenue and research}

The global world can learn from local communities as local, regional and global understanding of networks becomes part of community resources. Global professionals can also benefit from opportunities to work with local students and communities, research networks, and are provided with a chance to rethink the curriculum in a creative, innovative environment.

Additionally, it is also notable to focus on research results in the project. During the project period, a total of 14 papers related to the project have been released (see Table 3). Participants can be divided into professors, research students from Korea and local students. 


\section{Macrothink \\ International Journal of Regional Development \\ ISSN 2373-9851 2017, Vol. 4, No. 2}

Table 3. Project papers related to the project outcome

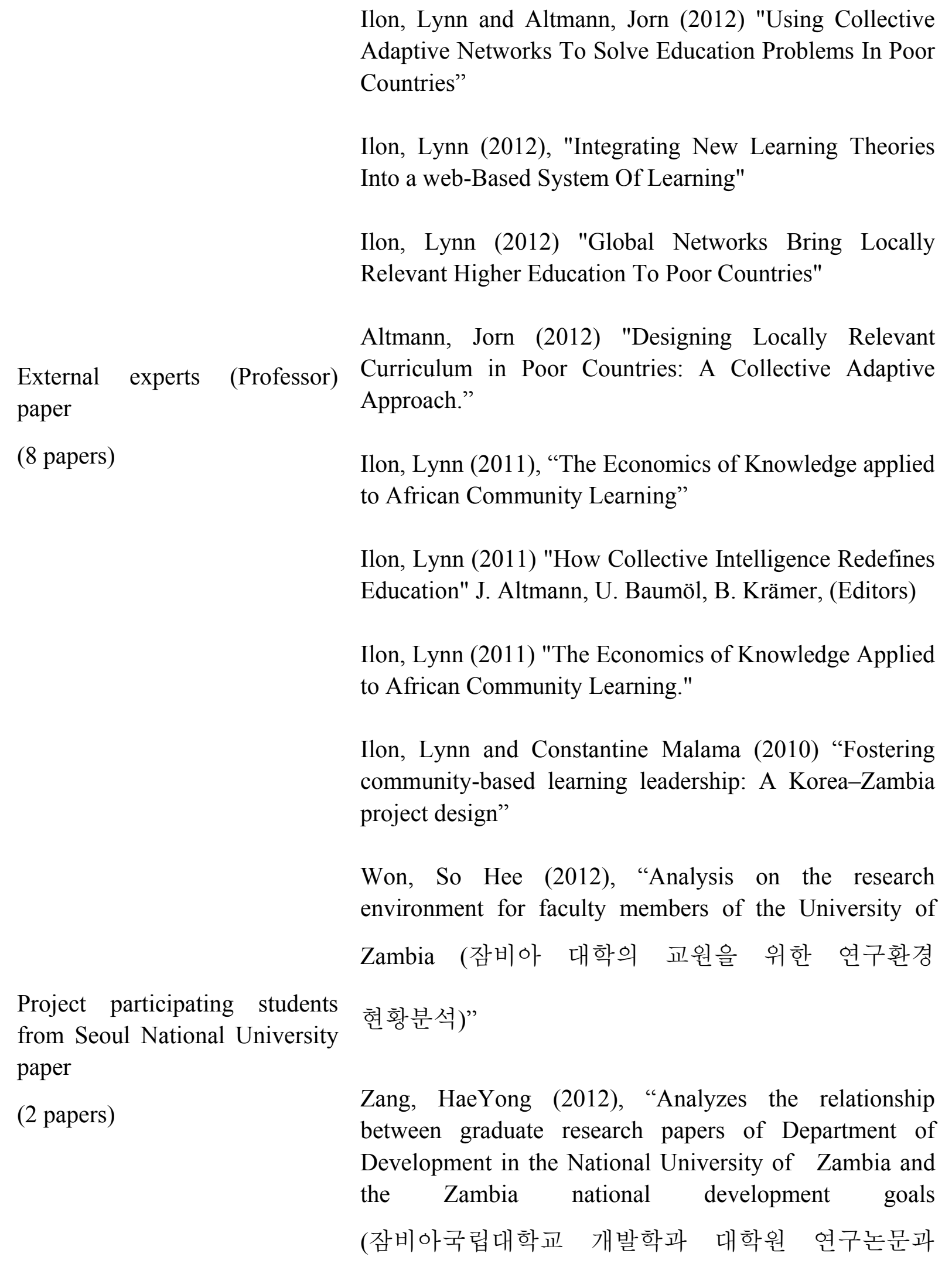


잠비아 국가 개발목표의 연관성 분석)”

Samson Kantini (2012) "Learning System For Local Community Sustainable Development"

Kantini, Mzizi and Ilon, Lynn (forthcoming) "Universities

Project participating researcher and students local paper

(4 papers) as Leaders in Community Development: The Case of Zambia," in Anthony Normore and Nancy D. Erbe (eds); International Perspectives on Leadership Development: A Multidisciplinary Approach. Bingley, UK: Emerald Group Publishers.

Anthony Kabwe\& John Shawa (2012), State of the Community Project

Specially, Table 3 shows that the subjects that students approached were different from those of the professionals. The global professor level offers a comprehensive approach based on a global perspective. But the subject of local students is approaching the local level based on local issues. And the strength of local student papers was the bottom-up approach based on the local community.

This demonstrates the potential that can be developed through the sharing of knowledge between a global perspective and a local perspective. The unique approach taken by global professionals in the past may be limited to solving local problems. This local perspective can once again be addressed from a global perspective. Finally this system can improve the quality of the local universities through joint regional research between global knowledge and local knowledge. Additionally, we can see the quantitative comparison between the pilot project and SNU.

\subsection{Learning 2.0 contribution to higher education in Africa}

Current theories on Learning 2.0 help us to understand how to apply Learning 2.0 with education. But such an approach has been mainly focused on developed countries. But Learning 2.0 is a new learning revolution that helps us to learn more effectively - even in the case of developing countries.

This case study shows that learning 2.0 in a knowledge economy can promote African higher education. It helps to reduce the cost of higher education for developing countries and provides improved learning experiences that are locally relevant. Additionally, it also provides a new higher education system that is economically sustainable for developing countries using the concept of knowledge economics, collective adaptive systems, social network theory and new learning theory. 
Table 4 compares recent e-learning programs with curriculum innovations elements of Learning 2.0.

Table 4. Learning 1.0 vs Leaning 2.0 elements from the project

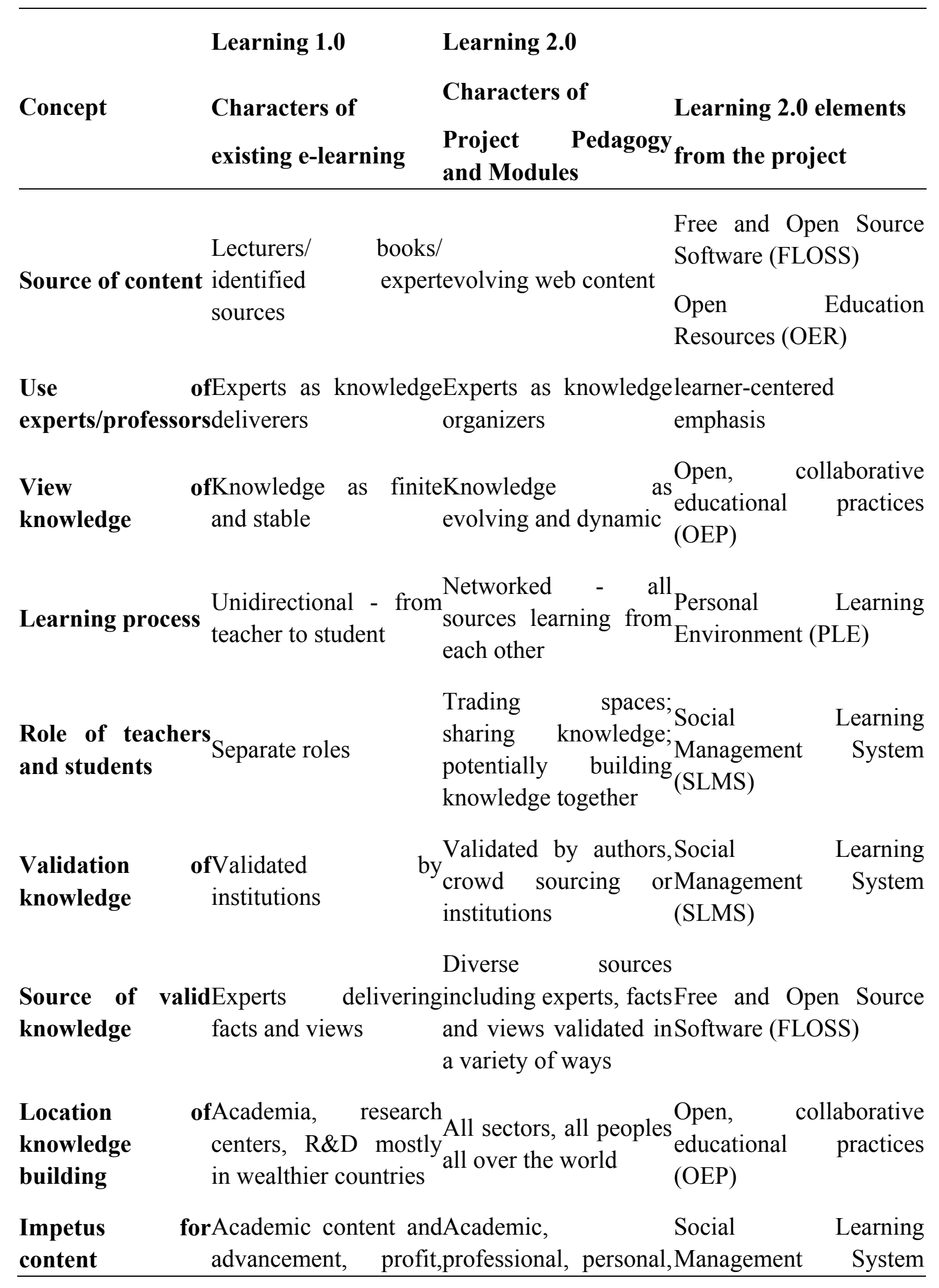




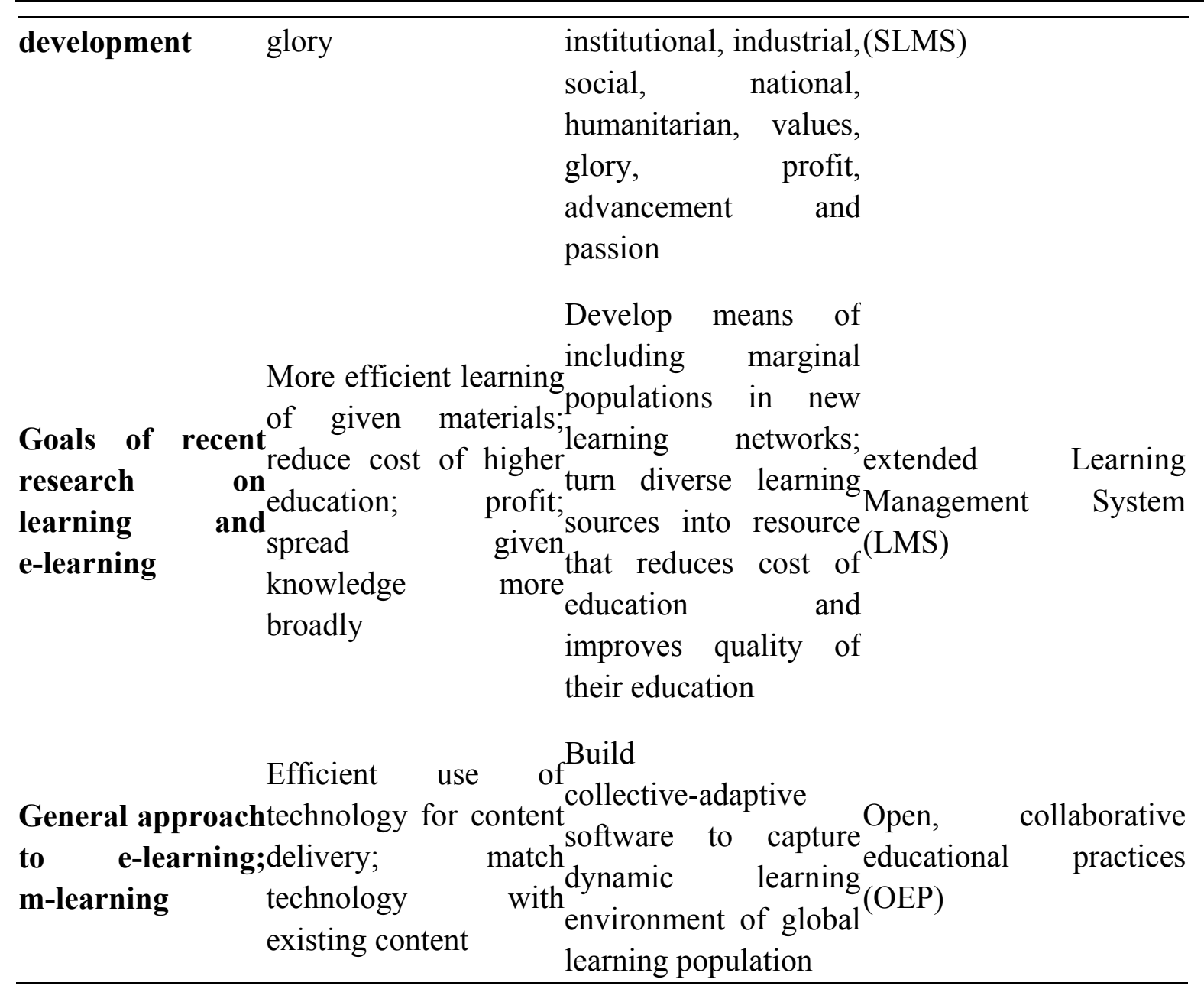

Table 4 shows how Learning 2.0 pedagogy and modules differ from the existing e-learning systems. Characteristics of the project pedagogy and modules can be connected with elements of Learning 2.0. This is especially the case with those Learning 2.0 elements which are factors that lower the cost of higher education in developing countries.

Another element of the project that could reduce the cost of higher education and is related to Learning 2.0 is a design that is still being worked on. It involves a modified open-source way of building curriculum as shown in Figure 6. 


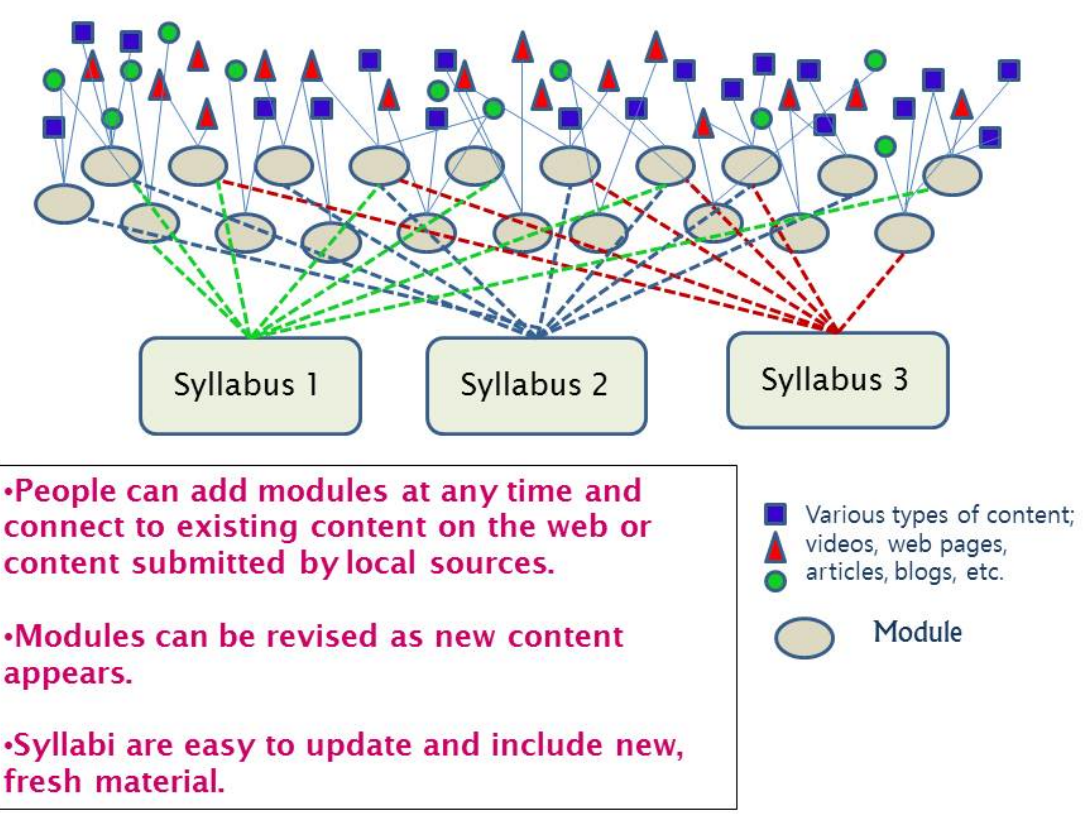

Figure 6. Module and Syllabus of GKA

Source: GKA (2013) Global Knowledge Alliance.

Since all information in the various modules will be open education resources there will be no copyright issues. Open Education Resources (OER) data will be used by default. Each module includes a variety of materials (articles, web pages, video, data, blogs, etc.) and will be available for one class but can be used across many institutes as the method is replicated in other countries. The modules are configured together as a group to form a course or syllabus. After that, students discuss the given contents and work together in order to build open, collaborative educational practices (OEP).

In contrast, Figure 2 shows a critical path to building schools in developing countries which was carried out in 2011 by Korea International Cooperation Agency (KOICA). This critical path model shows the need and procedures to establish a school in developing countries. The main issues were the budget, recruitment of instructors, student selection, teacher training, buildings \& facilities, equipment and curriculum development. 


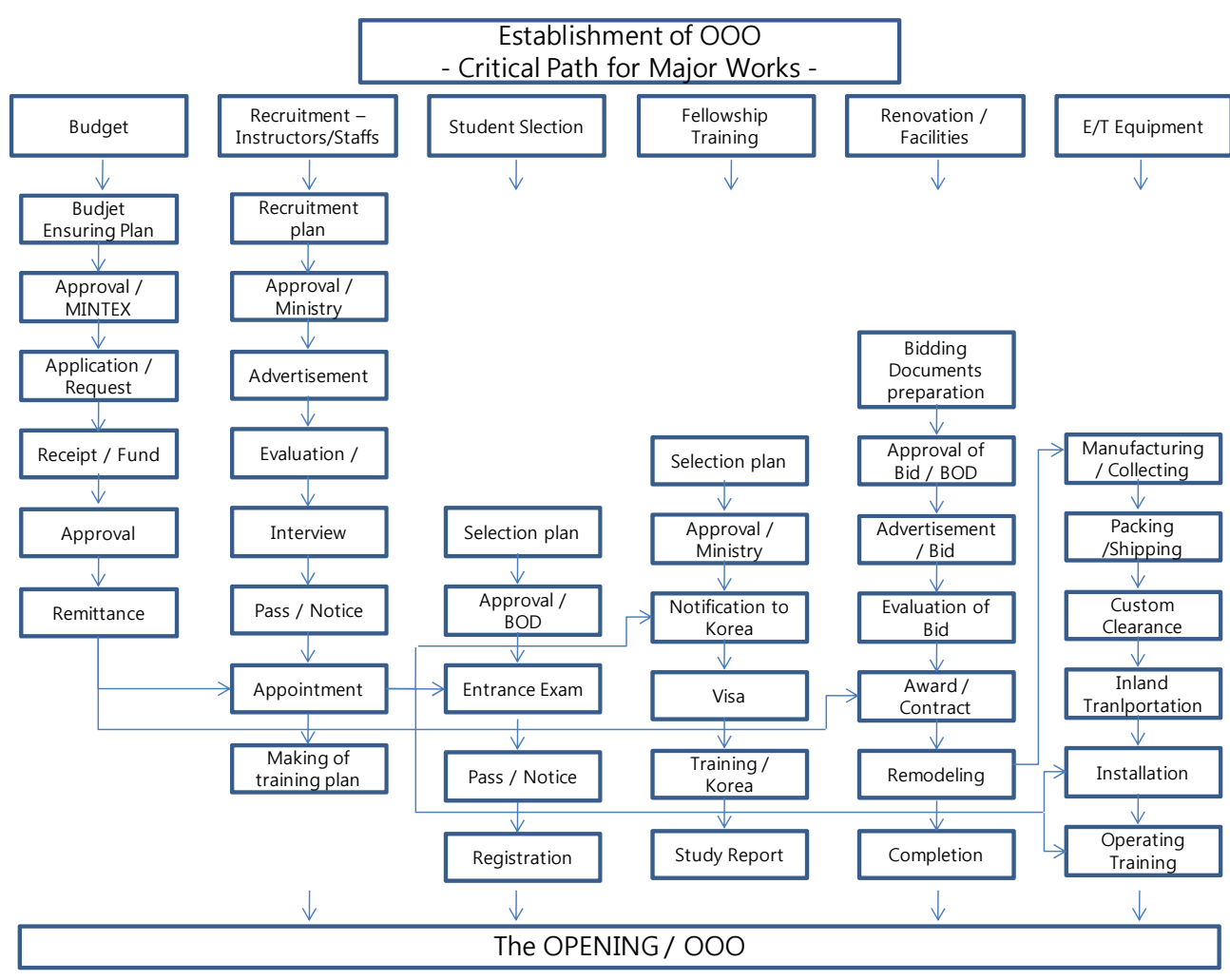

Figure 2. Critical Path for opening institute

Source: KOICA (2011).

This critical path approach, following a top-down, knowledge-delivery model of traditional schooling is enormously expensive. The major cost in the process of opening a new institute in developing countries can be summarized as follow: Cost of the school building \& facilities; Cost of recruiting professional instructors; Cost of developing qualified curriculums; Cost of tuition at the student level.

Using a model of Learning 2.0, emphasizing knowledge creation and networks of knowledge creation, costs a substantially reduced (from the critical path model) and learning is more dynamic. Table 5 summarizes the project model. 


\section{Macrothink \\ International Journal of Regional Development \\ ISSN 2373-9851 2017, Vol. 4, No. 2}

Table 5. Contribution of Learning 2.0 for Africa Higher Education

\begin{tabular}{|c|c|c|}
\hline $\begin{array}{l}\text { Learning } 2.0 \\
\text { contributions }\end{array}$ & Related concepts of Learning 2.0 & $\begin{array}{l}\text { Reduction of } \\
\text { knowledge delivering } \\
\text { cost }\end{array}$ \\
\hline $\begin{array}{l}\text { Cost } \\
\text { effectiveness }\end{array}$ & $\begin{array}{l}\text { Personal Learning Environment (PLE) } \\
\text { Free and Open Source Software (FLOSS) } \\
\text { Open Education Resources (OER) }\end{array}$ & $\begin{array}{l}\text { Cost of the school } \\
\text { building \& facilities } \\
\text { Cost of developing of } \\
\text { qualified curriculums }\end{array}$ \\
\hline $\begin{array}{l}\text { Accessibility } \\
\text { students }\end{array}$ & $\begin{array}{l}\text { Personal Learning Environment (PLE) } \\
\text { learner-centered emphasis }\end{array}$ & $\begin{array}{l}\text { Cost to pay fees at the } \\
\text { student level }\end{array}$ \\
\hline $\begin{array}{l}\text { Quality } \\
\text { development }\end{array}$ & $\begin{array}{l}\text { Open, collaborative educational practices } \\
\text { (OEP) } \\
\text { Open Education Resources (OER) }\end{array}$ & $\begin{array}{l}\text { Cost of recruiting } \\
\text { professional instructors } \\
\text { Cost of developing of } \\
\text { qualified curriculums }\end{array}$ \\
\hline $\begin{array}{l}\text { Local network } \\
\text { development }\end{array}$ & $\begin{array}{l}\text { Social Learning Management System } \\
\text { (SLMS) } \\
\text { extended Learning Management System } \\
\text { (LMS) } \\
\text { Open, collaborative educational practices } \\
\text { (OEP) }\end{array}$ & $\begin{array}{l}\text { Cost of developing of } \\
\text { qualified curriculums }\end{array}$ \\
\hline $\begin{array}{l}\text { North-South } \\
\text { network } \\
\text { development }\end{array}$ & $\begin{array}{l}\text { Social Learning Management System } \\
\text { (SLMS) } \\
\text { extended Learning Management System } \\
\text { (LMS) }\end{array}$ & $\begin{array}{l}\text { Cost of recruiting } \\
\text { professional instructors }\end{array}$ \\
\hline
\end{tabular}

The concept uses Learning 2.0, contributes to the expansion of higher education and reduces the cost of knowledge delivery for developing countries.

\section{Conclusion}

There are several critical limitations of the project. First, it is a pilot project. In order to demonstrate more tangible achievements, initial investment and time is needed.

Second, there has been an issue raised as to whether the higher education labor market is strong enough in Africa to accommodate students who have completed higher education. But this part is not a problem which requires a reduction of the higher education workforce. Highly educated human resources in developing countries not only have the role of supplying the existing labor market. Highly educated human resources can play a strategic thinking role tailored to the local and the global situation in developing countries and they are the driving force to open up new markets. Additionally, better and more graduates can help to expand the economy. Therefore, developing countries need to question to what extent human resources in higher education will be needed to secure national development in the future. 


\section{Macrothink}

Third, the biggest problem for expanding the growth of the higher education system is the cost. But higher education costs can be substantially changed it the methods of learning, knowledge creation and networks are allowed to be rethought. Each element of the higher education system can be analyzed and reduced in cost. Efforts have to be accompanied steadily to reduce costs and ensure quality for sustainable development in African higher education. The major cost in the existing education system is school buildings and facilities, recruiting professional instructors and developing curriculums. In addition, there is a cost to pay fees at the student level. Actually, this is the result of knowledge delivering costs.

The project model may not work for all cases of higher education, but it is a system which would likely work for many subject areas. The project practices which integrate Learning 2.0 help to lower costs through the efficient flow of knowledge. In addition, it can be seen that local students pay for tuition fees through the production of local knowledge.

In conclusion, three statements can be made by connecting Learning 2.0 in the knowledge economy and African higher education. First, higher education in developing countries is marginalized. But the promotion of higher education is essential for national development and human resource development in the knowledge economy. Second, characteristics of Learning 2.0 can be used to promote African higher education. Third, higher education through Learning 2.0 raises the possibility of sustainable development for higher education in Africa.

Eventually, the concept of the project shows that elements of the Learning 2.0 in the knowledge economy can help to spread higher education in developing countries.

\section{Reference}

Altmann, J. (2012). Designing Locally Relevant Curriculum in Poor Countries: A Collective Adaptive Approach. Presented at Future and emerging technologies Proactive Information Day, Brussels, 18 January 2012

Anthony, K., \& John, S. (2012), State of the Community Project, GKI a first trimester final paper.

Barro, R. J. (2001). Human capital: Growth, History, and Policy. The American Economic Review, 91(2), 12-17.

Barro, R. J. (2002). Education as a determinant of economic growth. In E. P. Lazear (ed.), Education in the twenty-first century, 9-24. The Hoover Institution.

Birdsall, N. (1996). Public spending on higher education in developing countries: Too much or too little? Economics of Education Review, 15(4), 407-419. https://doi.org/10.1016/s0272-7757(96)00028-3

Bloom, D. E., \& Rosovsky, H. (2006). Higher education in developing countries International Handbook of Higher Education, 443-459. https://doi.org/10.1007/978-1-4020-4012-2_22 
Bloom, D. E., Canning, D., \& Chan, K. (2006). Higher education and economic development in Africa (No. 102). Washington, DC: World Bank.

Conole, G. (2012). Designing for learning in an open world. 4, Springer.

Creţu, V. I. (2013). Social Media in Romanian Higher Education. Features, Uses and Arhitectures of Educational Microblogging Platforms.

De Meulemeester, J. L., \& Rochat, D. (1995). A causality analysis of the link between higher education and economic development. Economics of Education Review, 14(4), 351-361. https://doi.org/10.1016/0272-7757(95)00015-c

Dee, T. (2004). Are there civic returns to education? Journal of Public Economics, 88, 1697-1720. https://doi.org/10.3386/w9588

Denison, E. F. (1962). The sources of economic growth in the United States and the alternatives before us. NY: Committee for Economic Development. https://doi.org/10.2307/2228363

Drucker, P. (1966). 1993. HarperBusiness. New York.

Drucker, P. F. (1993). Post-Capitalist Economy. New York :Harper Collins,

Ehlers, U., Riley, D., \& Paviotti, G. (2008). QMPP-Quality Management in Peer Production. Quality for e-Learning 2.0: New Quality for New Learning. Presentation given at the Microlearning Conference 2008, "Microlearning\& Capacity Building", University of Innsbruck, 25 - 27 June 2008.

GKA. (2013). Global Knowledge Alliance. Retrieved from http://www.gkalinks.org

Harbison, F., \& Myers, C. A. (1964). Education, manpower, and economic growth. NY: McGraw-Hill.

Hwang, G. H., Chen, B., Chu, H. C., \& Cheng, Z. S. (2012). Development of a Web 2.0-based Ubiquitous Learning Platform for Schoolyard Plant Identification. In Wireless, Mobile and Ubiquitous Technology in Education (WMUTE), 2012 IEEE Seventh International Conference On. 259-263. https://doi.org/10.1109/wmute.2012.63

Ilon, L. (2011). How Collective Intelligence Redefines Education. In J. Altmann, U. Baumöl, B. Krämer (Eds.), in Advances in Intelligent and Soft Computing (vol. 113, pp. 94-104). Springer, Berlin/Heidelberg.

Ilon, L. (2011). The Economics of Knowledge applied to African Community Learning. International Conference on Knowledge Economy. East London, South Africa. 24-28 October 2011.

Ilon, L. (2012). Global Networks Bring Locally Relevant Higher Education To Poor Countries. Presented at Blurring Boundaries: International Education Development Conference, Georgia State University, 10-11.

Ilon, L. (2012). Integrating New Learning Theories Into a web-Based System of Learning. 
PPT, Society for Design and Process Science. June 10-14 2012 Berlin, Germany.

Ilon, L., \& Constantine, M. (2010). Fostering community-based learning leadership: A Korea-Zambia project design. In Anthony Normore (Ed.), Global Perspectives on Educational Leadership Reform. Bingley, UK: Emerald Group Publishing Limited, 285-300. https://doi.org/10.1108/s1479-3660(2010)0000011017

Ilon, L., \&Altmann, J. (2012). Using Collective Adaptive Networks to Solve Education Problems in Poor Countries (No. 201293). Seoul National University; Technology Management, Economics, and Policy Program (TEMEP).

Jokisalo, E., \&Riu, A. (2009). Informal learning in the era of Web 2.0. eLearning Papers, (14), 5 .

Kantini, M., \& Ilon, L. (forthcoming). Universities as Leaders in Community Development: The Case of Zambia. In Anthony Normore and Nancy D. Erbe (Eds.), International Perspectives on Leadership Development: A Multidisciplinary Approach. Bingley, UK: Emerald Group Publishers. https://doi.org/10.1108/s1479-3660(2013)0000020008

Kenkel, D. (1991). Health Behavior, Health Knowledge, and Schooling. Journal of Political Economy, 99(2), 287-305. https://doi.org/10.1086/261751

KOICA. (2011). Establishment of Garment Technology Institute project in Karachi: final report.

Leary, J., \& Berge, Z. (2007). Successful distance education programs in sub-Saharan Africa. Turkish Online Journal of Distance Education, 8(2), 136-145.

Lian, B., \& Oneal, J. R. (1997). Cultural diversity and economic development: A cross-national study of 98 countries, 1960-1985. Economic Development and Cultural Change, 46(1), 61-77.

Lin, T. C. (2004). The role of higher education in economic development: An empirical study of Taiwan case. Journal of Asian Economics, 15(2), 355-371. https://doi.org/10.1016/j.asieco.2004.02.006

Lochner, L., \&Moretti, E. (2003). The effect of education on crime: Evidence from prison inmates, arrests and self-Reports, NBER Working Paper, 8605. Cambridge: National Bureau of Economic Research. https://doi.org/10.3386/w8605

Morris, N. P., Ramsay, L., \& Chauhan, V. (2012). Can a tablet device alter undergraduate science students' study behavior and use of technology? Advances in Physiology Education, 36(2), 97-107. https://doi.org/10.1152/advan.00104.2011

OECD. (2011). Education at a Glance 2011: OECD Indicators. OECD. https://doi.org/10.1787/eag-2011-en

Park, T. S. (2002). Development of Knowledge Industries Impacts in Labor Markets (지식기반산업의 발전이 노동시장에 미치는 영향). The Journal of Management and 
Economics (經商論集경상논 접), Kyungpook National University, 30(1), 129-148.

Peña L. I. (2010). Framing the Digital Divide in Higher Education. Universities and Knowledge Society Journal, 7(1). https://doi.org/10.7238/rusc.v7i1.657

Pillay, P. (2008). Higher Education Funding Frameworks in SADC. Towards a Common Future: Higher education in the SADC region. Research findings from four SARUA Studies. Pretoria: SARUA, 125-195.

Psacharopoulos, G. (1984). The contribution of Education to economic growth: international comparisons. In Kendrick, J. W. (Ed.), International Conparisons of Productivity and Causes of the Slowdown. Cmabridge, MA: Ballinger Publishing Company, 335-355.

Romer, P. M. (1998). Innovation: The New Pump of Growth in Blueprint Magazine.

Samson, K. (2012). Learning System for Local Community Sustainable Development. Global Knowledge Institute.

Schultz, T. W. (1961). Investment in human capital. The American Economic Review, 51(1), $1-17$.

Schultz, T. W. (1963). The Economic Value of Education. NY: Columbia University Press.

Shaw, J. K., \& Allison, J. (1999). The intersection of the learning region and local and regional economic development: Analysing the role of higher education. Regional studies, 33(9), 896-902. https://doi.org/10.1080/00343409950075533

Strauss, J., Gertler, P., \& Rahman, O. (1993). Gender and life-cycle differentials in the patterns and determinants of adult health. Journal of Human Resources, 28(4), 791-837. https://doi.org/10.2307/146294

Taraghi, B. (2012). Ubiquitous Personal Learning Environment (UPLE). In Interactive Collaborative Learning (ICL), 2012 15th International Conference, 1-8. https://doi.org/10.1109/icl.2012.6402139

Thurow, L. C., \& Cunningham, J. (1999). Building wealth. Harper Collins, 116-129.

Toffler, A. (1980). The Third Wave. New York: Bantam Books.

Toffler, A. (1990). Powershift: Knowledge, Wealth and Violence at the Edge of the 21st Century. New York : Bantam Books.

Won, S. H. (2012). Analysis on the research environment for faculty members of the University of Zambia (잠비아 대학의 교원을 위한 연구환경 현황분석), Field Study Report "Educational Program and Research Competency Development Project for Innovative Learning Center in Zambia”, National Research Foundation of Korea

World Bank. (2009). Accelerating catch-up: Tertiary education for growth in Sub-Saharan 


\section{IIMacrothink}

International Journal of Regional Development

ISSN 2373-9851 2017, Vol. 4, No. 2

Africa. Washington D.C.: World Bank. https://doi.org/10.1596/978-0-8213-7738-3

Zang, H. Y. (2012). Analyzes the relationship between graduate research papers of Department of Development in the National University of Zambia and the Zambia national development goals (잠비아 국립대학교개발학과 대학원 연구논문과 잠비아 국가 개발목표의 연관성 분석). Field Study Report "Educational Program and Research Competency Development Project for Innovative Learning Center in Zambia”, National Research Foundation of Korea

Zho, W. H. (2010). Economics in the world of work (일의 세계경제학 2nd ed.). Bobmunsa, Seoul.

\section{Copyright Disclaimer}

Copyright for this article is retained by the author(s), with first publication rights granted to the journal.

This is an open-access article distributed under the terms and conditions of the Creative Commons Attribution license (http://creativecommons.org/licenses/by/3.0/). 
文件名:

目录:

模板:

标题:

主题:

作者:

关键词:

备注:

创建日期:

修订号:

上次保存日期:

上次保存者:

编辑时间总计：

上次打印时间:

打印最终结果

页数:

字数:

字符数:
Template-Paper-IJRD

C:IUsers $\backslash$ Phone\Documents

C: $\mid$ Users $\backslash$ Phone $\backslash A p p D a t a \backslash R o a m i n g \backslash$ Microsoft $\backslash$ Templates $\backslash$ Norma
Macrothink Institute

Macrothink Institute, www.macrothink.org

2011/9/24 14:25:00

72

2017/7/20 13:05:00

Phone

250 分钟

2017/7/20 13:06:00

21

6,314 (约)

35,994 (约) 